Article

\title{
Luminescence of Agrellite Specimen from the Kipawa River Locality
}

\author{
Maria Czaja ${ }^{1, *(1)}$ and Radosław Lisiecki ${ }^{2}$ \\ 1 Faculty of Natural Sciences, Institute of Earth Sciences, University of Silesia, Będzińska 60, \\ 41-200 Sosnowiec, Poland \\ 2 Institute of Low Temperature and Structure Research, Polish Academy of Sciences, W. Trzebiatowski \\ Institute, Okólna 2, 50-422 Wrocław, Poland; r.lisiecki@intibs.pl \\ * Correspondence: maria.czaja@us.edu.pl
}

Received: 29 October 2019; Accepted: 30 November 2019; Published: 3 December 2019

Abstract: Using steady-state luminescence measurements, the luminescence spectra of $\mathrm{Ce}^{3+}, \mathrm{Pr}^{3+}$, $\mathrm{Nd}^{3+}, \mathrm{Sm}^{3+}, \mathrm{Eu}^{3+}, \mathrm{Dy}^{3+}, \mathrm{Er}^{3+}$ and $\mathrm{Yb}^{3+}$ for the agrellite sample from the Kipawa River region have been measured. The emission spectra of $\mathrm{Eu}^{3+}$ and $\mathrm{Dy}^{3+}$ next to those of $\mathrm{Sm}^{3+}$ and $\mathrm{Pr}^{3+}$ have been measured for characteristic excitation conditions. The most efficient luminescence activator in the studied sample was $\mathrm{Ce}^{3+}$. This ion was also a sensitizer of $\mathrm{Pr}^{3+}, \mathrm{Sm}^{3+}, \mathrm{Eu}^{3+}$, and $\mathrm{Dy}^{3+}$ luminescence.

Keywords: agrellite; lanthanide ion; energy transfer

\section{Introduction}

Agrellite is a rather rare mineral and is usually found in pegmatite lenses and pods or in mafic gneisses in a regionally metamorphosed agpatic alkali rock complex. It occurs with eudialyte, britholite, aegirine, as well as miserite, vlasovite, calcite, fluorite, clinohumite, gittinsite, norbergite, zircon, biotite, phlogopite, galena, and quartz. The most known localities of it are the Sheffield Lake complex, Kipawa River, Villedieu Township, Québec (Canada), Dara-i-Pioz massif, Alai Range, Tien Shan Mountains (China), (Tajikistan), the Murun massif, southwest of Olekminsk, Yakutia, (Russia) and Wausau complex, and finally, Marathon Co. in Wisconsin (USA). Among the minerals from the Kipawa River complex, only britholite, fluorite, calcite, miserite, and zircon are predisposed to exhibit fluorescence from lanthanide ions. However, no such reports are known so far. The knowledge of agrellite luminescence comes from websites only [1-3], and from the Gorobets and Rogojine review book [4]. According to these sources, agrellite has a dull pink color or a bright pink color under shortwave ultraviolet (SW UV) or longwave ultraviolet (LW UV, respectively. The following emission centers have been observed [4]: $\mathrm{Ce}^{3+}, \mathrm{Dy}^{3+}$, and $\mathrm{Sm}^{3+}$ for samples from the Kipawa River; $\mathrm{Fe}^{3+}, \mathrm{Mn}^{2+}$, $\mathrm{Eu}^{2+}$, and presumed $\mathrm{Nd}^{3+}$ for samples from the Yakutia; and of $\mathrm{Ce}^{3+}$ and $\mathrm{Mn}^{2+}$ for specimens from the Dara-i-Pioz. The latest results of spectroscopic investigation of agrellite samples from Dara-i-Pioz (Tajikistan) and Murun massif (Russia) shows luminescence from $\mathrm{Ce}^{3+}$ and EPR spectra of $\mathrm{Mn}^{2+}$ [5].

An attempt was also made to synthesize sodium calcium silicate with an initial composition such as agrellite [6]. These materials were doped with $\mathrm{Mn}^{2+}(1 \%, 2 \%$, and $3 \%), \mathrm{Ce}^{3+}(0.5 \%)$, and $\mathrm{Tb}^{3+}(4 \%)$, but as a result of synthesis, multiphase nanoparticles composed of wollastonite $2 \mathrm{M} \mathrm{CaSiO}_{3}$, devitrite $\mathrm{Na}_{2} \mathrm{Ca}_{3} \mathrm{Si}_{6} \mathrm{O}_{16}$, and cristobalite $\mathrm{SiO}_{2}$ was formed.

The current paper presents the preliminary results of a study of the luminescence properties of agrellite $\mathrm{NaCa}_{2} \mathrm{Si}_{4} \mathrm{O}_{10} \mathrm{~F}$ specimens from the Kipawa Alkaline Complex, Québec, Canada.

Agrellite crystallized in triclinic, space group $\mathrm{P}(-1)$, and unit cell parameters are: $\mathrm{a}=7.759$ (2) $\AA$, $\mathrm{b}=18.946$ (3) $\AA, \mathrm{c}=6.986$ (1) $\AA, \alpha=89.88^{\circ}, \beta=116.65^{\circ}, \gamma=94.34^{\circ}, \mathrm{Z}=4$ [7]. All atoms in the agrellite lattice are present in general positions and the Wyckoff site of all atoms is denoted as $2 \mathrm{i}$. The crystal 
structure of agrellite consists of two different $\mathrm{NaO}_{8}$ distorted cubes polyhedra, two $\mathrm{CaO}_{5} \mathrm{~F}$ octahedra (hereinafter referred to as $\mathrm{Ca} 1 \mathrm{~B}$ and $\mathrm{Ca} 2 \mathrm{~A}$ ), and two $\mathrm{CaO}_{6} \mathrm{~F}_{2}$ polyhedra (named as Ca1A and $\mathrm{Ca} 2 \mathrm{~B}$ ) coupled with two different $\mathrm{Si}_{8} \mathrm{O}_{20}$ chains [7]. The mean of $\mathrm{Ca}-\mathrm{O}$ and $\mathrm{Ca}-\mathrm{F}$ distances are smaller for $\mathrm{CaO}_{5} \mathrm{~F}$ octahedra and equal for $\mathrm{Ca} 1 \mathrm{~B}$ and $\mathrm{Ca} 2 \mathrm{~A}$, respectively $2.381 \AA$, $2.192 \AA, 2.367 \AA$, and $2.201 \AA$ than $\mathrm{CaO}_{6} \mathrm{~F}_{2}$ and equal for $\mathrm{Ca} 1 \mathrm{~A}$ and $\mathrm{Ca} 2 \mathrm{~B}$, respectively 2.574, 2.402, $2.615 \AA$ and $2.454 \AA$ (Figure $1 \mathrm{a}, \mathrm{b}$ ).

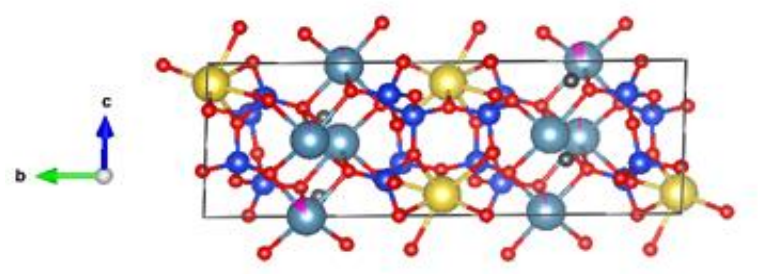

a)

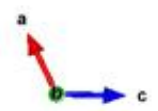

b)

)

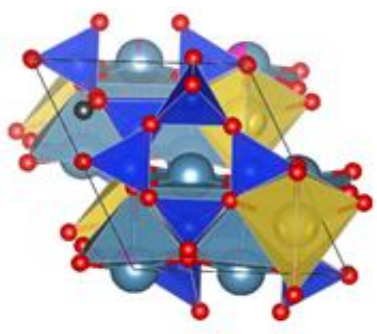

Figure 1. A sketch of agrellite structure: (a) on (100) plane; oxygen atoms-small red balls, silicon atoms—small blue balls, calcium atoms—big blue balls, Ca1A site—big blue and magenta balls, sodium atoms-big yellow balls, and fluorine atoms—small black balls; (b) on (010) plane; small dark blue tetrahedra in $\mathrm{Si}_{8} \mathrm{O}_{20}$ chains, big light blue $\mathrm{Ca}-\mathrm{O}, \mathrm{F}$ and yellow $\mathrm{NaO}_{8}$ polyhedra; small red balls-oxygen atoms.

\section{Materials and Methods}

The agrellite sample studied here takes the form of fine lath-shaped aggregates measuring from a few to over $100 \mathrm{~mm}$ in length. It has a greenish-white color (Figure 2a) which changes to lavender-pink under mid UV (Figure 2b).

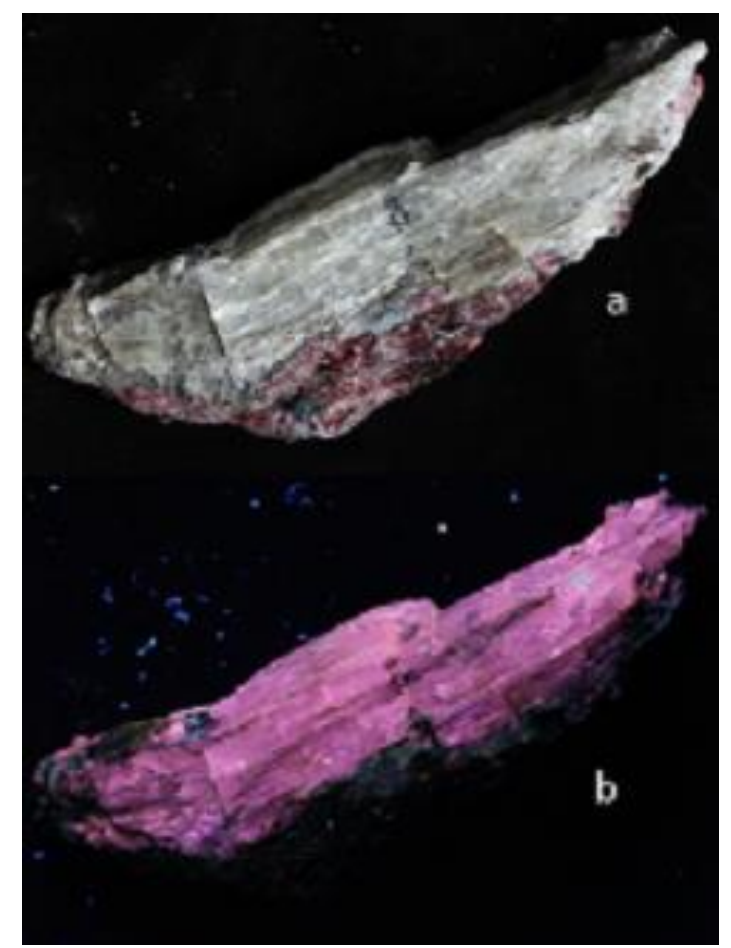

Figure 2. Photos of agrellite sample under white light (a) and LW UV (365 nm) (b).

Rare earth elements (REE) concentrations in the studied agrellite crystal were measured by the ISP-MS method at ACMA Lab (Canada), and the results are listed in Table 1. Steady-state fluorescence measurements for ions shown in the chemical analysis were performed using a Jobin-Yvon (SPEX) 
spectrofluorimeter FLUOROLOG 3-12 (Jobin-Yvon, Grenoble, France SPEX at room temperature using a $450 \mathrm{~W}$ xenon lamp, a double-grating monochromator, and a Hamamatsu 928 photomultiplier (Hamamatsu Photonics, Shizuoka, Japan). The wavelength range for emission and excitation spectra was from 250 to $900 \mathrm{~nm}$, and the resolution no lower than $1 \mathrm{~nm}$. For such conditions, the emission and excitation spectra of $\mathrm{Ce}^{3+}, \mathrm{Pr}^{3+}, \mathrm{Sm}^{3+}, \mathrm{Eu}^{3+}, \mathrm{Dy}^{3+}$, and $\mathrm{Er}^{3+}$ in the $\mathrm{UV}-\mathrm{Vis}$ range were recorded. The emission spectra of $\mathrm{Nd}^{3+}, \mathrm{Yb}^{3+}$, and $\mathrm{Er}^{3+}$ also in the NIR range were measured utilizing a Dongwoo Optron DM711 monochromator (MaeSan-Ri, Opo-Eup, GwangJu-Si, Gyeonggi-Do, Korea) coupled with a Hamamatsu 928 photomultiplier (Hamamatsu Photonics, Shizuoka, Japan), and an InGaAs detector (Hamamatsu Photonics, Shizuoka, Japan) or PbS detector (Hamamatsu Photonics, Shizuoka, Japan) depending on the spectral region. An InGaAs diode laser (Appolo Instruments, Irvine, USA) emitting infrared radiation at $975 \mathrm{~nm}$ and an $\mathrm{AlGaAs}$ diode laser (CNI, Changchun, China) emitting at $808 \mathrm{~nm}$ were used as continuous wave excitation sources.

Table 1. Concentration of some transition elements in the studied agrellite sample.

\begin{tabular}{cccccccc}
\hline \multicolumn{8}{c}{ Contents (ppm) } \\
\hline $\mathrm{Y}$ & $\mathrm{La}+\mathrm{Lu}$ & $\mathrm{Ce}$ & $\mathrm{Pr}$ & $\mathrm{Nd}$ & $\mathrm{Sm}$ & $\mathrm{Eu}$ & $\mathrm{Gd}$ \\
$>2000$ & $>2000$ & $>2000$ & 1174 & $>2000$ & 1034 & 136 & 1265 \\
\hline \multicolumn{7}{c}{ Contents (ppm) } \\
\hline $\mathrm{Tb}$ & $\mathrm{Dy}$ & $\mathrm{Ho}$ & $\mathrm{Er}$ & $\mathrm{Tm}$ & $\mathrm{Yb}$ & $\mathrm{Mn}$ & $\mathrm{Fe}$ \\
221 & 1419 & 282 & 772 & 93 & 458 & 1454 & $<2000$ \\
\hline
\end{tabular}

\section{Results}

In the studied agrellite specimen, the minimum content of lanthanide ions as a potential luminescence activator can be estimated as $1.0 \%$ (Table 1). If the distribution of these ions is uniform, then these ions are present in every 2.5 unit cell. The maximum distance among $4 \mathrm{f}$ ions is not less than $17.5 \AA$ and not more than $47.25 \AA$.

Using steady-state fluorescence measurements, the emission of the following lanthanide ions were measured: $\mathrm{Ce}^{3+}, \mathrm{Pr}^{3+}, \mathrm{Nd}^{3+}, \mathrm{Sm}^{3+}, \mathrm{Eu}^{3+}, \mathrm{Er}^{3+}$, and $\mathrm{Yb}^{3+}$. Despite the significant $\mathrm{Mn}$ content, the emission spectra of $\mathrm{Mn}^{2+}$ were not measured. Unlike the [4] data, no emission from $\mathrm{Fe}^{3+}$ was obtained.

\section{1. $\mathrm{Nd}^{3+}, \mathrm{Yb}^{3+}$, and $\mathrm{Er} \mathrm{r}^{3+}$ Luminescence}

The emission of $\mathrm{Nd}^{3+}$ was measured as a group of three multiples (Figure 3). The most intense was measured at 1046, 1060, 1064, 1078, and $1092 \mathrm{~nm}$ and corresponds to the ${ }^{4} \mathrm{~F}_{3 / 2} \rightarrow{ }^{4} \mathrm{I}_{11 / 2}$ transition. Another group of lines at $879,885,893,905$, and $917 \mathrm{~nm}$ is associated with the ${ }^{4} \mathrm{~F}_{3 / 2} \rightarrow{ }^{4} \mathrm{I}_{9 / 2}$, transitions and the last with lines at 1313, 1335, and $1340 \mathrm{~nm}$-with the ${ }^{4} \mathrm{~F}_{3 / 2} \rightarrow{ }^{4} \mathrm{I}_{13 / 2}$ transitions. The emission spectrum of $\mathrm{Yb}^{3+}$ was not very intense (inset of Figure 3) and band $979 \mathrm{~nm}$ corresponds to the transition ${ }^{2} \mathrm{~F}_{5 / 2} \rightarrow{ }^{2} \mathrm{~F}_{7 / 2}$.

It was expected that the measurement of distinct emission lines of $\mathrm{Er}^{3+}$ would be possible due to the significant content of this ion and its high luminescence efficiency. However, the emission bands of Er ${ }^{3+}$ corresponding to the ${ }^{2} \mathrm{H}_{11 / 2} \rightarrow{ }^{4} \mathrm{I}_{15 / 2},{ }^{4} \mathrm{~S}_{3 / 2} \rightarrow{ }^{4} \mathrm{I}_{15 / 2}$ and ${ }^{4} \mathrm{~F}_{9 / 2} \rightarrow{ }^{4} \mathrm{I}_{15 / 2}$ transitions and usually measured at a 500-600 nm range were not clearly visible for steady-state luminescence measurements using a xenon lamp excitation, contrary to time-resolved measurements [8]. It has previously been verified [9] that for steady-time measurements using a xenon lamp, the most convenient excitation for $\mathrm{Er}^{3+}$ is $\lambda=377 \mathrm{~nm}$. However, for the studied agrellite specimen, only a weak emission band at $543 \mathrm{~nm}$ was measured (Figure 4). In the NIR range, the distinct emission band at $1533 \mathrm{~nm}(1554 \mathrm{~nm}, 1512 \mathrm{~nm}$, and $1488 \mathrm{~nm}$ ) was measured as a result of the ${ }^{4} \mathrm{I}_{13 / 2} \rightarrow{ }^{4} \mathrm{I}_{15 / 2}$ transition (Figure 5). Using laser excitation, emission bands of ${ }^{2} \mathrm{H}_{11 / 2} \rightarrow{ }^{4} \mathrm{I}_{15 / 2},{ }^{4} \mathrm{~S}_{3 / 2} \rightarrow{ }^{4} \mathrm{I}_{15 / 2}$, and ${ }^{4} \mathrm{~F}_{9 / 2} \rightarrow{ }^{4} \mathrm{I}_{15 / 2}$ transitions were also obtained (inset in Figure 5). However, the intensities of these bands at 520 and $550 \mathrm{~nm}$ were very weak, not only in comparison with the $\mathrm{Er}^{3+}$ emission in the NIR range but also with the $\mathrm{Sm}^{3+}$ and $\mathrm{Pr}^{3+}$ emission lines, 
although the samarium or praseodymium concentration was not much higher than the Er content (Figure 6).

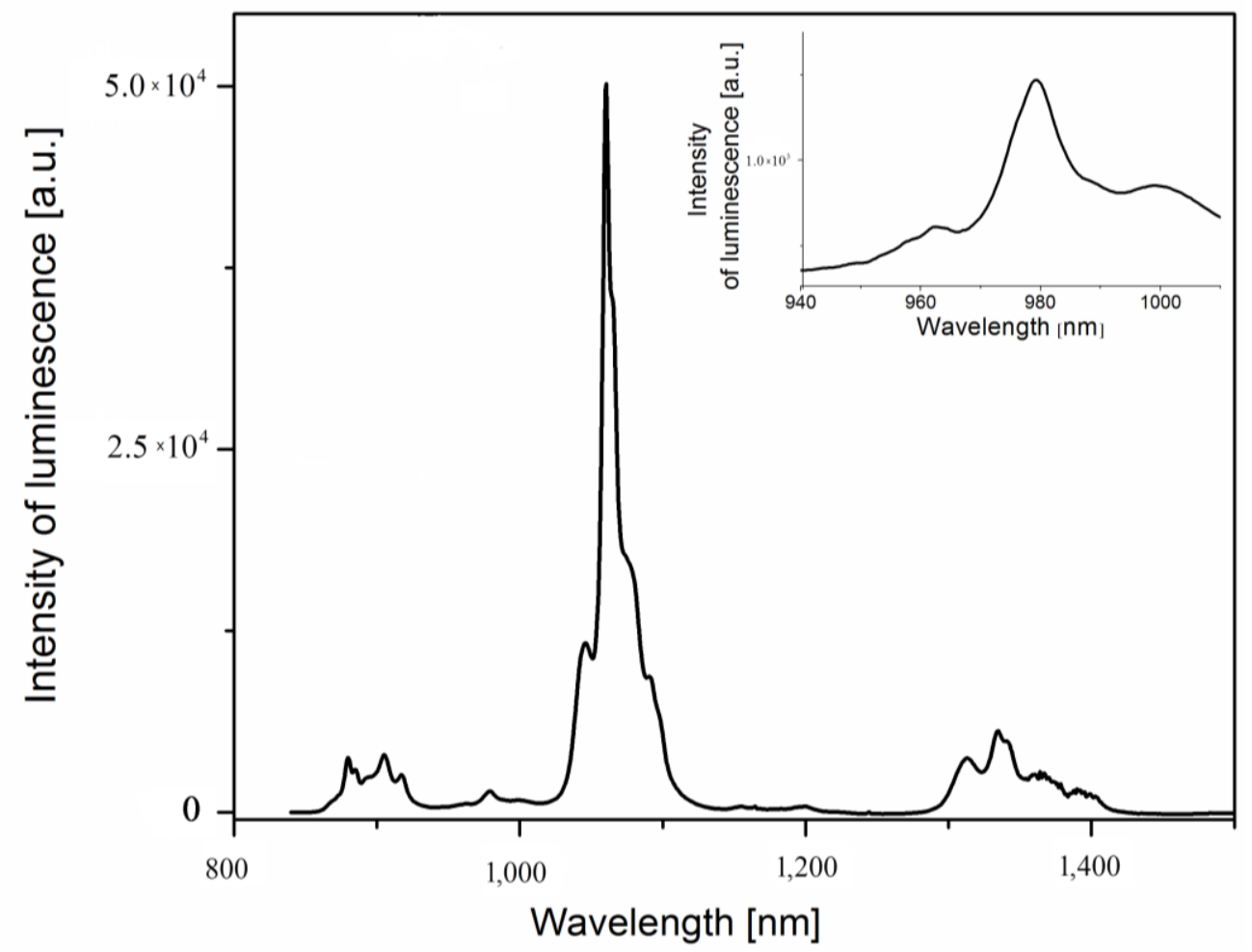

Figure 3. Luminescence spectra of $\mathrm{Nd}^{3+}$ and $\mathrm{Yb}^{3+}$ in agrellite sample.

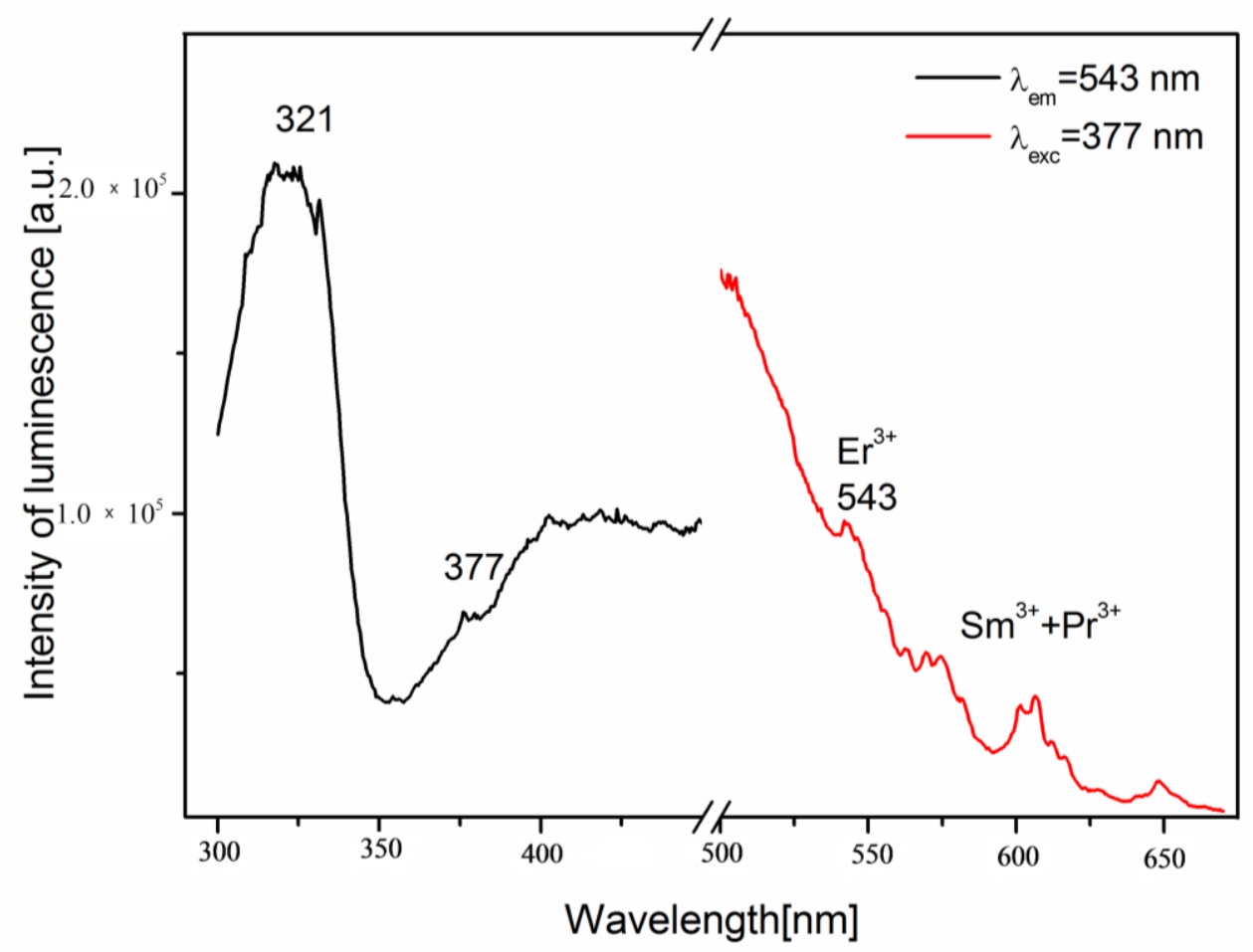

Figure 4. Photoluminescence spectra of $\mathrm{Er}^{3+}$ from the agrellite sample. 


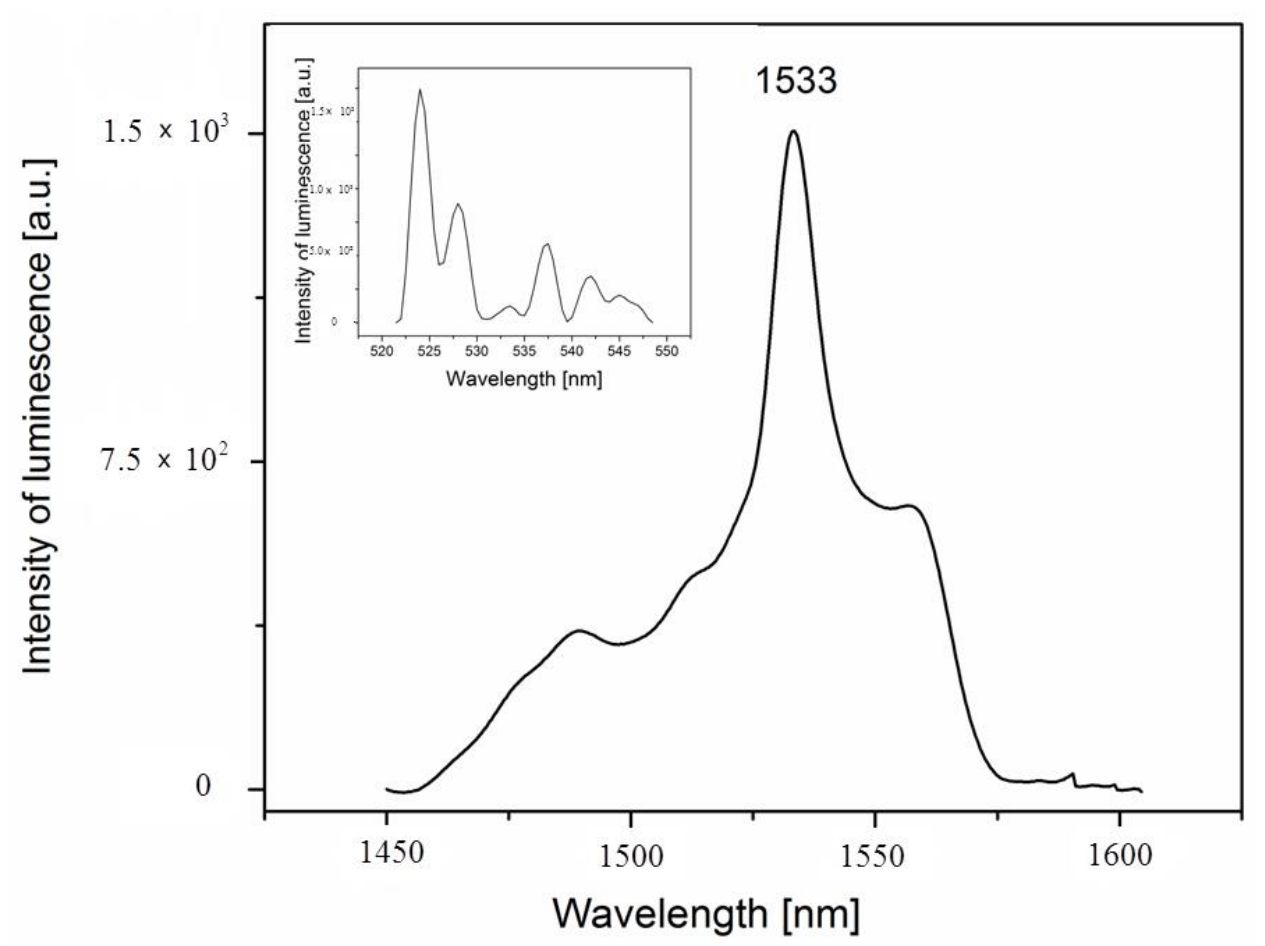

Figure 5. Emission spectra of $\mathrm{Er}^{3+}$ from agrellite samples measured under laser excitations.

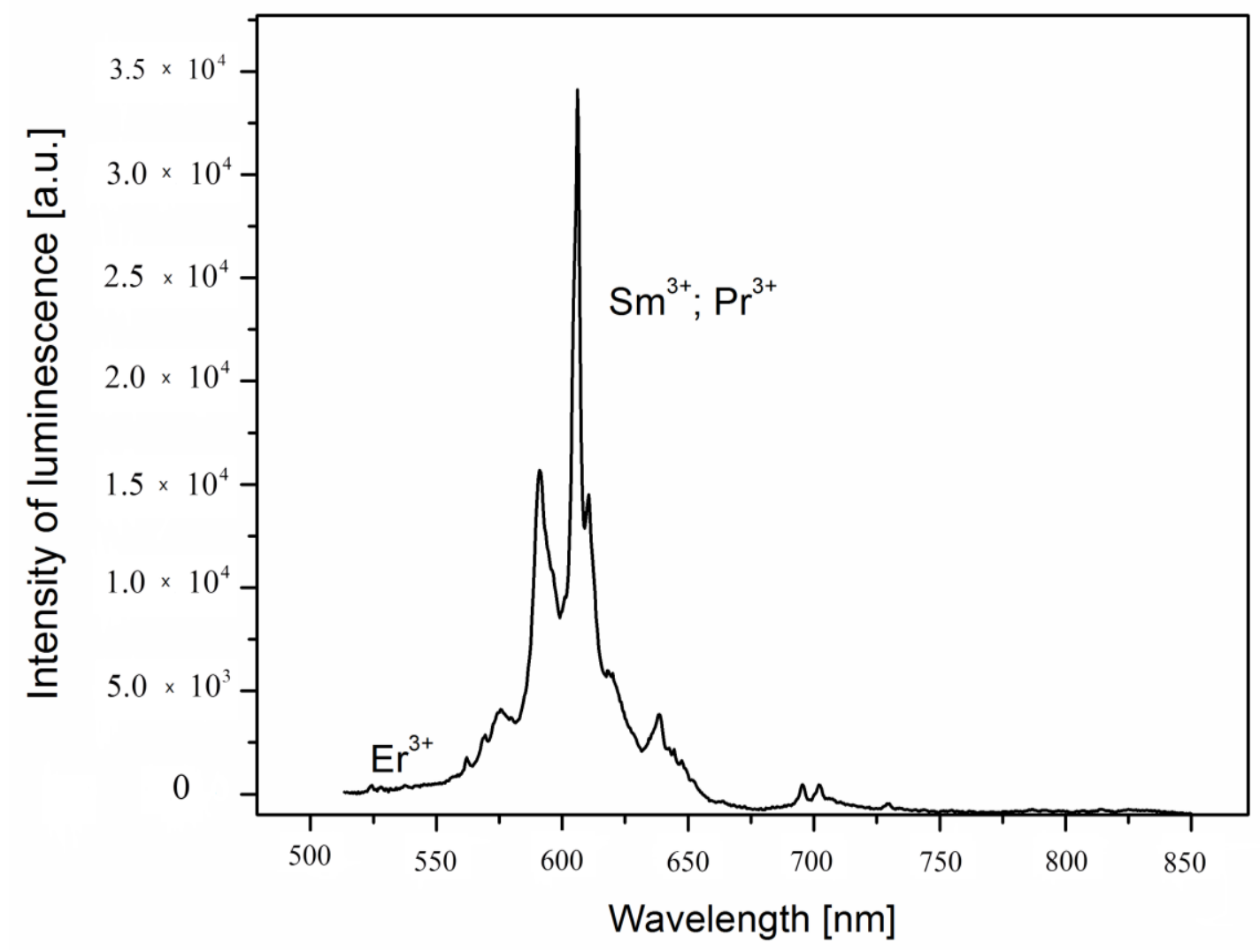

Figure 6. Emission spectra of $\mathrm{Sm}^{3+}, \mathrm{Pr}^{3+}$, and $\mathrm{Er}^{3+}$ in Vis range measured under laser excitation.

\section{2. $\mathrm{Ce}^{3+}$ Fluorescence}

The cerium content in the studied agrellite sample was high. Electric-dipole $4 \mathrm{f}-5 \mathrm{~d}$ transitions are even and spin allowed with the oscillator strength at half-width and short luminescence decay time. 
Cerium $\mathrm{Ce}^{3+}$ is often added to synthetic crystals because of its well-known properties as an efficient sensitizer of luminescence. Luminescent materials doped with $\mathrm{Ce}^{3+}$ can efficiently absorb excitation energy. A very intensive emission band at $388 \mathrm{~nm}$ has been measured (Figure 7). The zero phonon line (ZPL) position was designated in the point of spectral overlap of the excitation and emission curves, i.e., at $\lambda=337 \mathrm{~nm}\left(29,673 \mathrm{~cm}^{-1}\right)$. The Stokes shift $\Delta S$, as the energy difference between absorption/excitation and emission maxima of transition between the lowest $5 d$ and the $4 f$ ground states, is equal to 1567 $\mathrm{cm}^{-1}$. This value is not very high, probably owing to the high coordination number around $\mathrm{Ce}^{3+}$ and the long Ca-O distance [10,11]. For the lowest Raman frequency of agrellite $331 \mathrm{~cm}^{-1}$, the Huang-Rhys parameter $S$ is equal to $S=2.8$, so electron-phonon coupling may be recognized as intermediate.

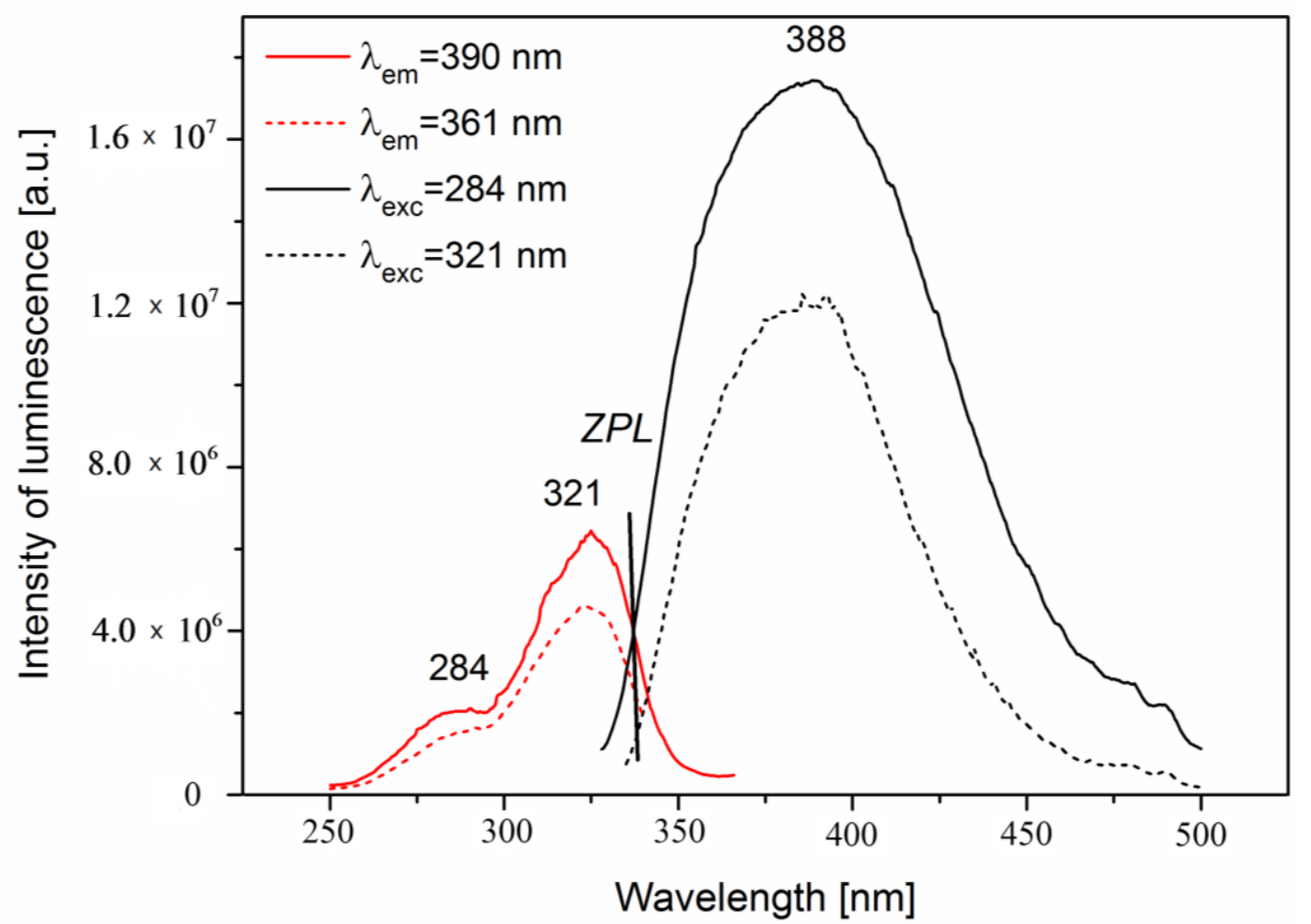

Figure 7. Photoluminescence spectra of $\mathrm{Ce}^{3+}$ in agrellite sample.

On the excitation spectra, two bands at $284 \mathrm{~nm}$ and $321 \mathrm{~nm}$ were recorded, so the crystal-field splitting $10 D q$ of $5 \mathrm{~d}$ level was estimated as $4059 \mathrm{~cm}^{-1}$. The upper excited level of $\mathrm{Ce}^{3+}$ is $\mathrm{T}_{2 \mathrm{~g}}$ and the lower is $\mathrm{E}_{\mathrm{g}}$. The $10 \mathrm{Dq}$ parameter for $\mathrm{Ce}^{3+}$ usually has a value in the $5000-10,000 \mathrm{~cm}^{-1}$ range. For the studied crystal it was slightly smaller because the $\mathrm{Ca}-\mathrm{O}$ length in agrellite is larger than in other $\mathrm{Ca}$-minerals, for example fluor-apatite. The emission band of $\mathrm{Ce}^{3+}$ is nearly symmetric, although it was fitted to two Gaussian components with maxima at $28,023 \mathrm{~cm}^{-1}$ and $25,819 \mathrm{~cm}^{-1}\left(R^{2}=0.998\right)$ that can be discerned, (Figure 8), which correspond to the transition terminated on the ${ }^{2} \mathrm{~F}_{5 / 2}$ and ${ }^{2} \mathrm{~F}_{7 / 2}$ levels.

The intensity of the $\mathrm{Ce}^{3+}$ emission band at $388 \mathrm{~nm}$ measured for $\lambda_{\mathrm{exc}}=284 \mathrm{~nm}$ was almost 1.5 times higher than those observed for $\lambda_{\text {exc }}=321 \mathrm{~nm}$, despite the power of the xenon lamp is lower at $\lambda=284 \mathrm{~nm}$ than at $321 \mathrm{~nm}$. This may indicate that a significant part of the excitation energy at $\lambda_{\text {exc }}=321 \mathrm{~nm}$ in the studied mineral transferred to other luminescence centers.

In [5] for the agrellite sample from Dara-i-Pioz, the emission and excitation spectra of $\mathrm{Ce}^{3+}$ have been presented. The Ce-content in this sample was 1160-1263 ppm, distinctly less than for the Kipawa River (Table 1). The emission band of $\mathrm{Ce}^{3+}$ was measured at $370 \mathrm{~nm}$ as a rather symmetrical band, while on the excitation spectrum, the following bands have been measured: 190, 220, 245, 281, and $317 \mathrm{~nm}$. The differences in emission and excitation bands for the sample from Dara-i-Pioz (Tajikistan) and the Kipawa River are certainly due to the change in the $\mathrm{Ce}-\mathrm{O}$ bonding length in both samples. 
It can be concluded that the crystal-field strength for the Kipawa River specimen is less than for the sample from Dara-i-Pioz. The possibility of $\mathrm{Ce}^{4+}$ presence and $\mathrm{Ce}^{4+}$ charge transfer bands on the absorption spectrum at $400 \mathrm{~nm}$, which may be due to the gray color of agrellite crystals, was also assumed [5].

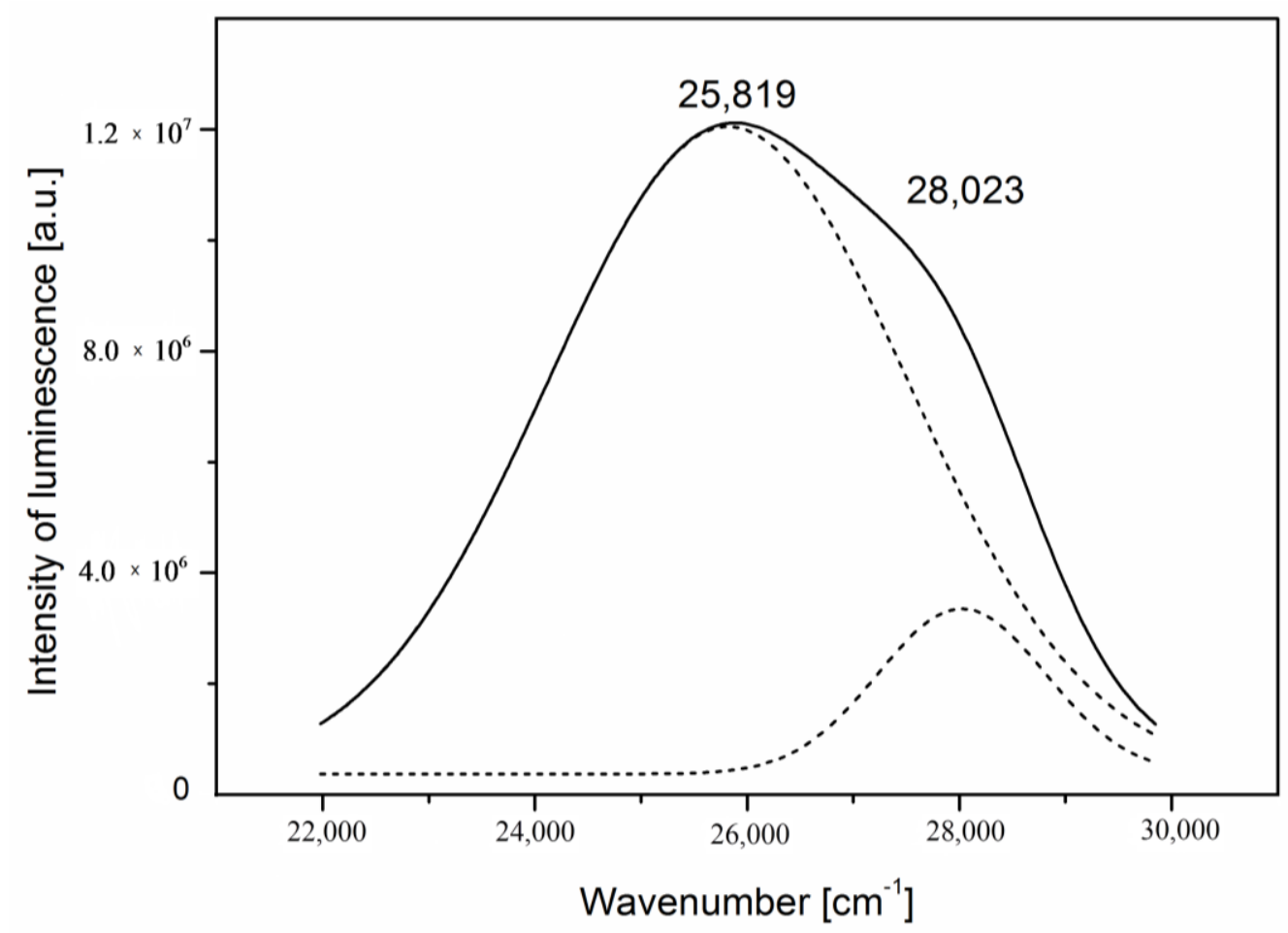

Figure 8. The deconvolution of emission band of $\mathrm{Ce}^{3+} \mathrm{E}_{\mathrm{g}}(4 \mathrm{f} 5 \mathrm{~d}) \rightarrow 4 \mathrm{f}\left({ }^{2} \mathrm{~F}_{5 / 2},{ }^{2} \mathrm{~F}_{7 / 2}\right)$ into two components.

For the studied agrellite sample, the energy transfer between $\mathrm{Ce}^{3+}$ and $\mathrm{Dy}^{3+}, \mathrm{Eu}^{3+}, \mathrm{Sm}^{3+}$, and $\mathrm{Pr}^{3+}$ were found. Energy transfer in phosphors with sensitizer-activator ion pairs means that part of the excitation energy of the sensitizer ion transfers to activator ion through a non-radiative process and it subsequently enhances or generates the emission of the activator. The energy transfer among $\mathrm{Ce}^{3+}$ and other $4 \mathrm{f}$ ions is well known and used to synthesize phosphors with expected properties [12-18].

$\mathrm{Gd}^{3+}$ is another activator with intense absorption and emission lines in the UV range. Its excitation line is usually at $275 \mathrm{~nm}$ and corresponds to ${ }^{8} \mathrm{~S}_{7 / 2} \rightarrow{ }^{6} \mathrm{I}_{7 / 2}$ transition, while emission could occur either from the ${ }^{6} \mathrm{I}_{7 / 2}$ or the ${ }^{6} \mathrm{P}_{7 / 2}$ level as a $312 \mathrm{~nm}$ band. The $\mathrm{Gd}^{3+}$ emission was rarely measured for mineral samples. However, the $\mathrm{Gd}^{3+}$ luminescence was found in some scheelite, anhydrite, apatite, and fluorite specimens [19]. Moreover, it was found for $\mathrm{CaF}_{2}$ [19] that due to energy transfer $\left({ }^{6} \mathrm{I}_{7 / 2}-{ }^{6} \mathrm{P}_{7 / 2}\right)\left(\mathrm{Gd}^{3+}\right)-\left({ }^{3} \mathrm{~F}_{2},{ }^{3} \mathrm{H}_{6}{ }^{-3} \mathrm{H}_{4}\right)\left(\mathrm{Pr}^{3+}\right)$, the emission at $275 \mathrm{~nm}$ is weakened, whereas at $312 \mathrm{~nm}$ it is enhanced. After using laser induction [4], time-resolved measurements of the $\mathrm{Gd}^{3+}$ fluorescence for zircon, anhydrite, and hardystonite have been prepared. The energy transfer among $\mathrm{Gd}^{3+}$ and many $\mathrm{RE}^{3+}$ have been analyzed [10-27]. For the studied agrellite sample, the energy transfer from $\mathrm{Gd}^{3+}$ to $\mathrm{RE}^{3+}$ could be excluded. The validity of this thesis is based on the fact that:

(a) for all substances known from existing literature, the $\mathrm{Gd}_{2} \mathrm{O}_{3}$ content was about $25 \mathrm{~mol} \%$ or more.

(b) the excitation and emission lines of $\mathrm{Gd}^{3+}$ did not appear in the agrellite spectra at all, although certain narrow lines should be clearly visible.

\subsubsection{Energy Transfer $\mathrm{Ce}^{3+}-\mathrm{Dy}^{3+}$}

The intense emission of $\mathrm{Dy}^{3+}$ related to ${ }^{4} \mathrm{~F}_{9 / 2} \rightarrow{ }^{6} \mathrm{H}_{13 / 2}$ transition at $575 \mathrm{~nm}$ was measured for the most suitable excitation at $\lambda=438 \mathrm{~nm}$ (solid olive line in Figure 9). However, for $\lambda_{\text {exc }}=321 \mathrm{~nm}$, 
not only was $\mathrm{Ce}^{3+}$ emission at $388 \mathrm{~nm}$ measured, but so was a $\mathrm{Dy}^{3+}$ emission band (solid red lines in Figure 9), and luminescence intensity was stronger than for the previous excitation. Moreover, on the excitation spectrum at $\lambda_{\mathrm{em}}=575 \mathrm{~nm}$ corresponded to the ${ }^{4} \mathrm{~F}_{9 / 2} \rightarrow{ }^{6} \mathrm{H}_{13 / 2}$ transition (dash-dot olive line in Figure 9), while the excitation band at $321 \mathrm{~nm}$ prevails on the $\mathrm{Dy}^{3+}$ band. It appears that the $\mathrm{Ce}^{3+}$ excitation band overlapped on the $\mathrm{Dy}^{3+} 4 \mathrm{f}^{9}-4 \mathrm{f}^{8} 5 \mathrm{~d}$ broadband or that it is transferred to the ${ }^{4} \mathrm{~K}_{15 / 2,17 / 2}$ excited Dy ${ }^{3+}$ level.

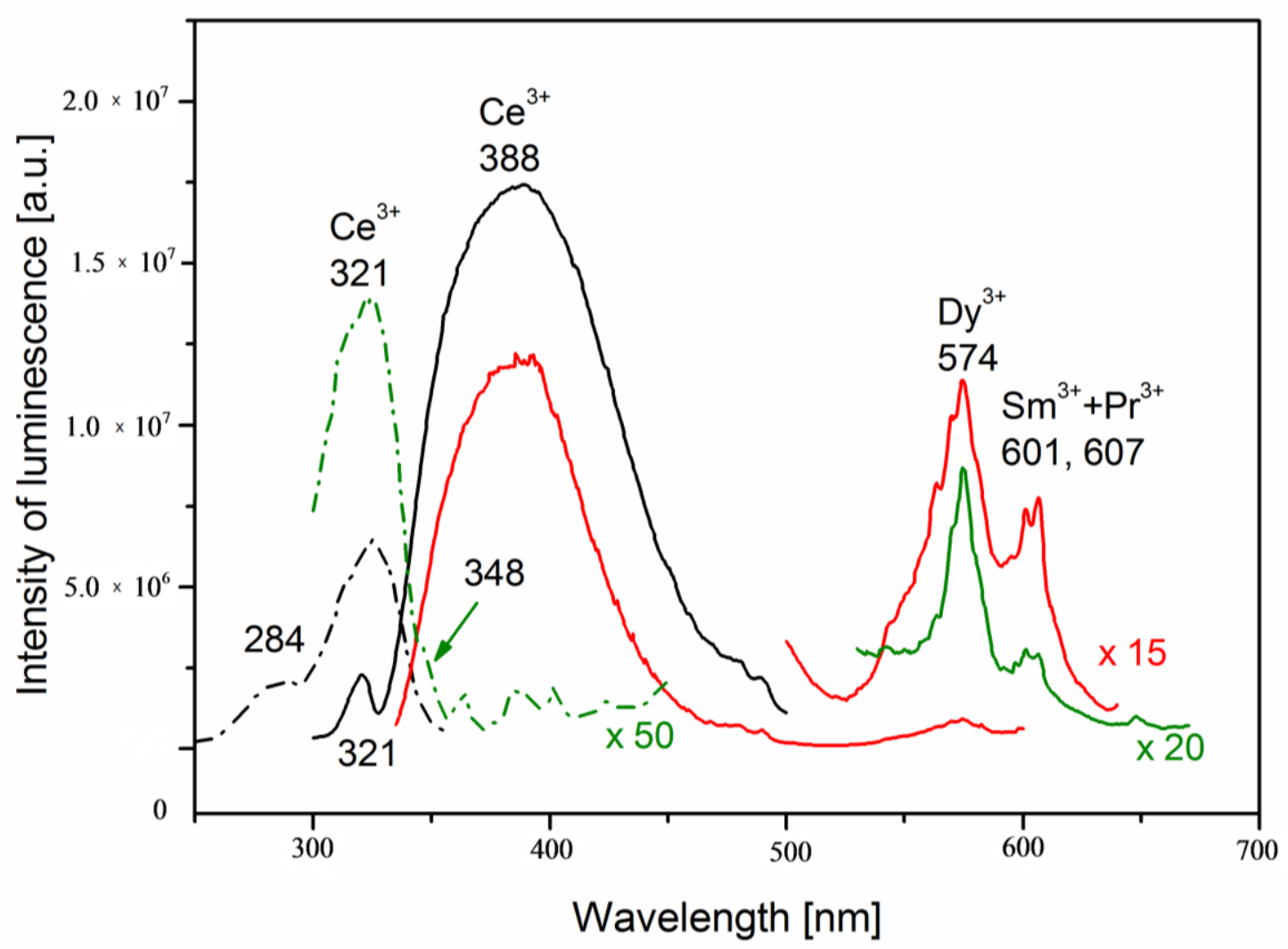

Figure 9. The photoluminescence spectra of $\mathrm{Dy}^{3+}, \mathrm{Sm}^{3+}$, and $\mathrm{Pr}^{3+}$ and $\mathrm{Ce}^{3+}$. Solid lines-emission spectra: black- $\lambda_{\text {exc }}=284 \mathrm{~nm}$, red- $\lambda_{\text {exc }}=321 \mathrm{~nm}$, olive line $-\lambda_{\text {exc }}=348 \mathrm{~nm}$. Dash-dot lines-excitation spectra: dark olive line $-\lambda_{\mathrm{em}}=575 \mathrm{~nm}$, black line $-\lambda_{\mathrm{em}}=388 \mathrm{~nm}$.

\subsubsection{Energy Transfer $\mathrm{Ce}^{3+}-\mathrm{Sm}^{3+}, \mathrm{Pr}^{3+}$, and $\mathrm{Eu}^{3+}$}

The efficient emission of $\mathrm{Sm}^{3+}$ and $\mathrm{Pr}^{3+}$ was also found for agrellite crystal. In the spectral range of 550-700 nm, the emission lines of these two ions are located close to each other and are: at $562 \mathrm{~nm}$ and $569 \mathrm{~nm}$ as ${ }^{4} \mathrm{G}_{5 / 2} \rightarrow{ }^{6} \mathrm{H}_{5 / 2}$ transition of $\mathrm{Sm}^{3+}$; at $601 \mathrm{~nm}$ and $607 \mathrm{~nm}$ of both $\mathrm{Sm}^{3+}{ }^{4} \mathrm{G}_{5 / 2} \rightarrow{ }^{6} \mathrm{H}_{7 / 2}$ and $\mathrm{Pr}^{3+1} \mathrm{D}_{2} \rightarrow{ }^{3} \mathrm{H}_{4}+{ }^{3} \mathrm{P}_{0} \rightarrow{ }^{3} \mathrm{H}_{6}$ transitions; and at $648 \mathrm{~nm}$ mainly for $\mathrm{Pr}^{3+}$ transition ${ }^{3} \mathrm{P}_{0} \rightarrow{ }^{3} \mathrm{~F}_{2}$. As it was found earlier [9], the most convenient excitation for $\mathrm{Sm}^{3+}$ is the 399-402 nm line, while for $\mathrm{Pr}^{3+}$ it is $480 \mathrm{~nm}$ (Figure 10).

For $\lambda_{\text {exc }}=402 \mathrm{~nm}$ excitation, beside of $\mathrm{Sm}^{3+}$ and $\mathrm{Pr}^{3+}$ emission lines, the $\mathrm{Eu}^{3+}$ emission at $613 \mathrm{~nm}$ attributed to transition ${ }^{5} \mathrm{D}_{0} \rightarrow{ }^{7} \mathrm{~F}_{2}$ have been measured as well (Figure 11).

No emission of $\mathrm{Eu}^{2+}$ was found. The emission of $\mathrm{Eu}^{3+}$ as a characteristic line at $613 \mathrm{~nm}$ was obtained for the most convenient excitation $\lambda_{\text {exc }}=393 \mathrm{~nm}$ (Figure 12). However, this excitation also caused $\mathrm{Sm}^{3+}$ and $\mathrm{Pr}^{3+}$ emission. 


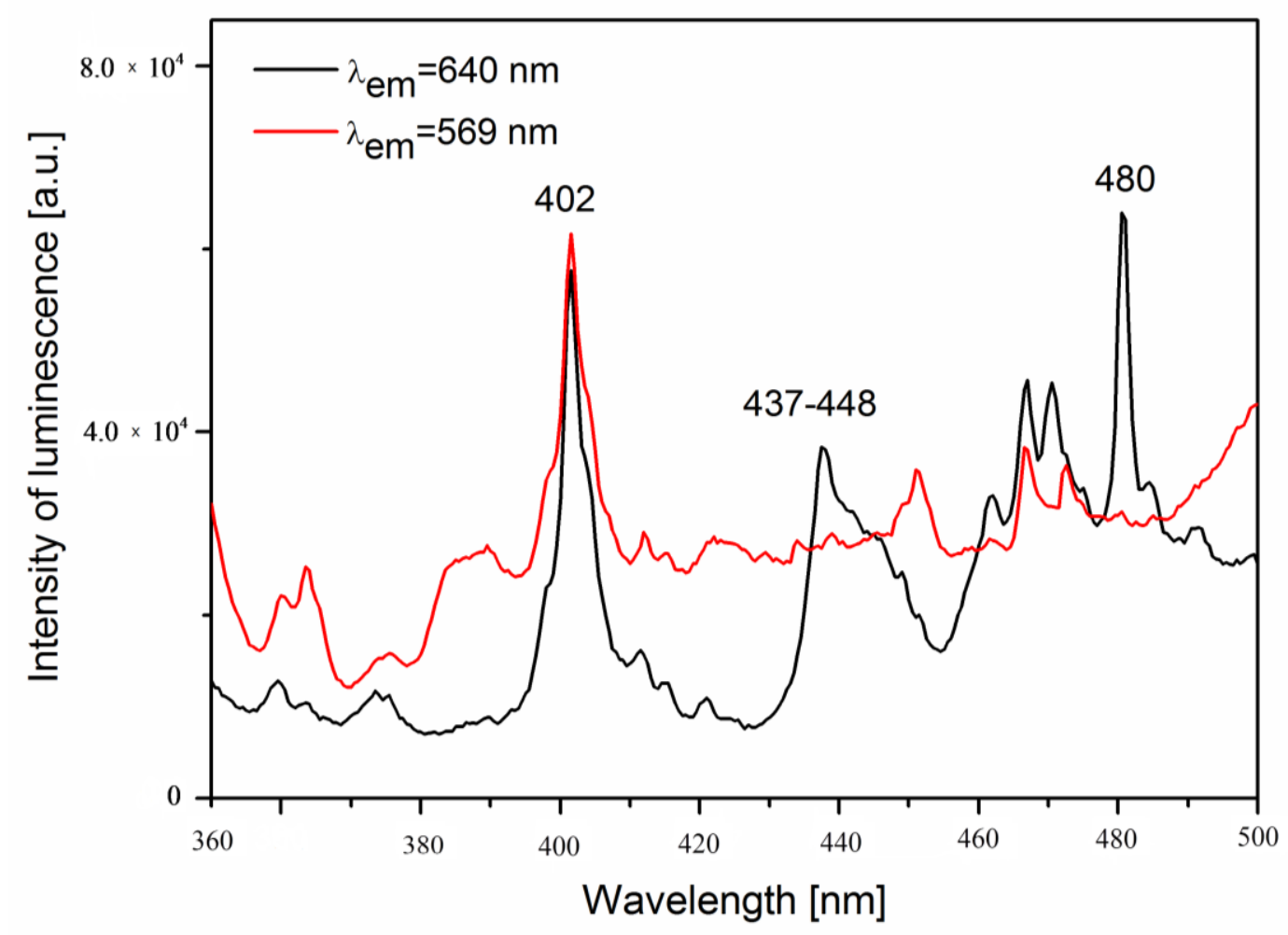

Figure 10. Excitation spectra characteristic for $\operatorname{Pr}^{3+}$ (black line) and $\mathrm{Sm}^{3+}$ (red line).

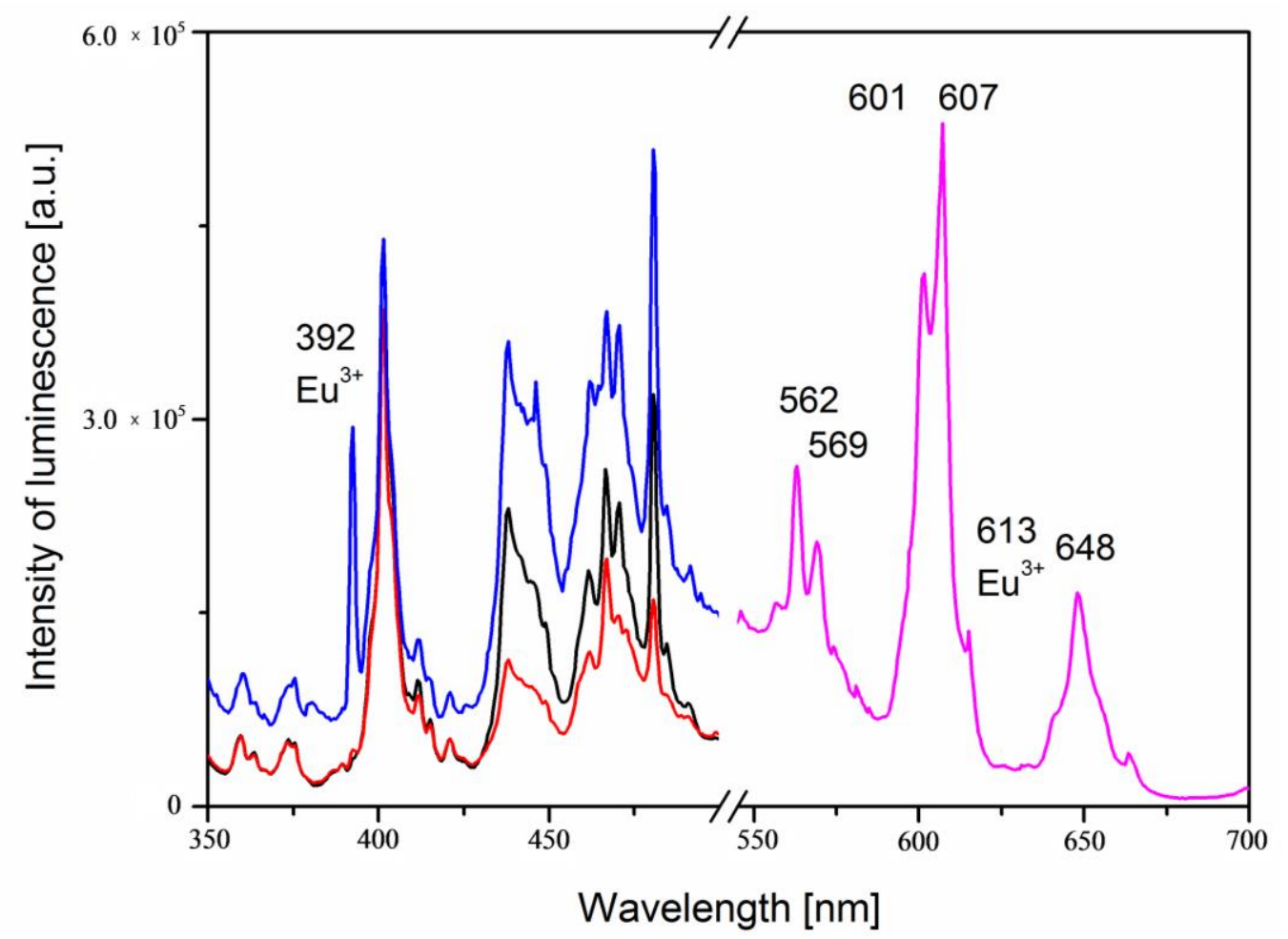

Figure 11. The photoluminescence spectra of $\mathrm{Pr}^{3+}, \mathrm{Sm}^{3+}$, and $\mathrm{Eu}^{3+}$ in agrellite. Emission spectrum measured at $\lambda_{\mathrm{exc}}=402 \mathrm{~nm}$ excitation-magenta line, excitation spectrum at $\lambda_{\mathrm{em}}=613 \mathrm{~nm}$-blue line, excitation spectrum at $\lambda_{\mathrm{em}}=601 \mathrm{~nm}$-red line, and excitation spectrum at $\lambda_{\mathrm{em}}=648 \mathrm{~nm}$-black line. 


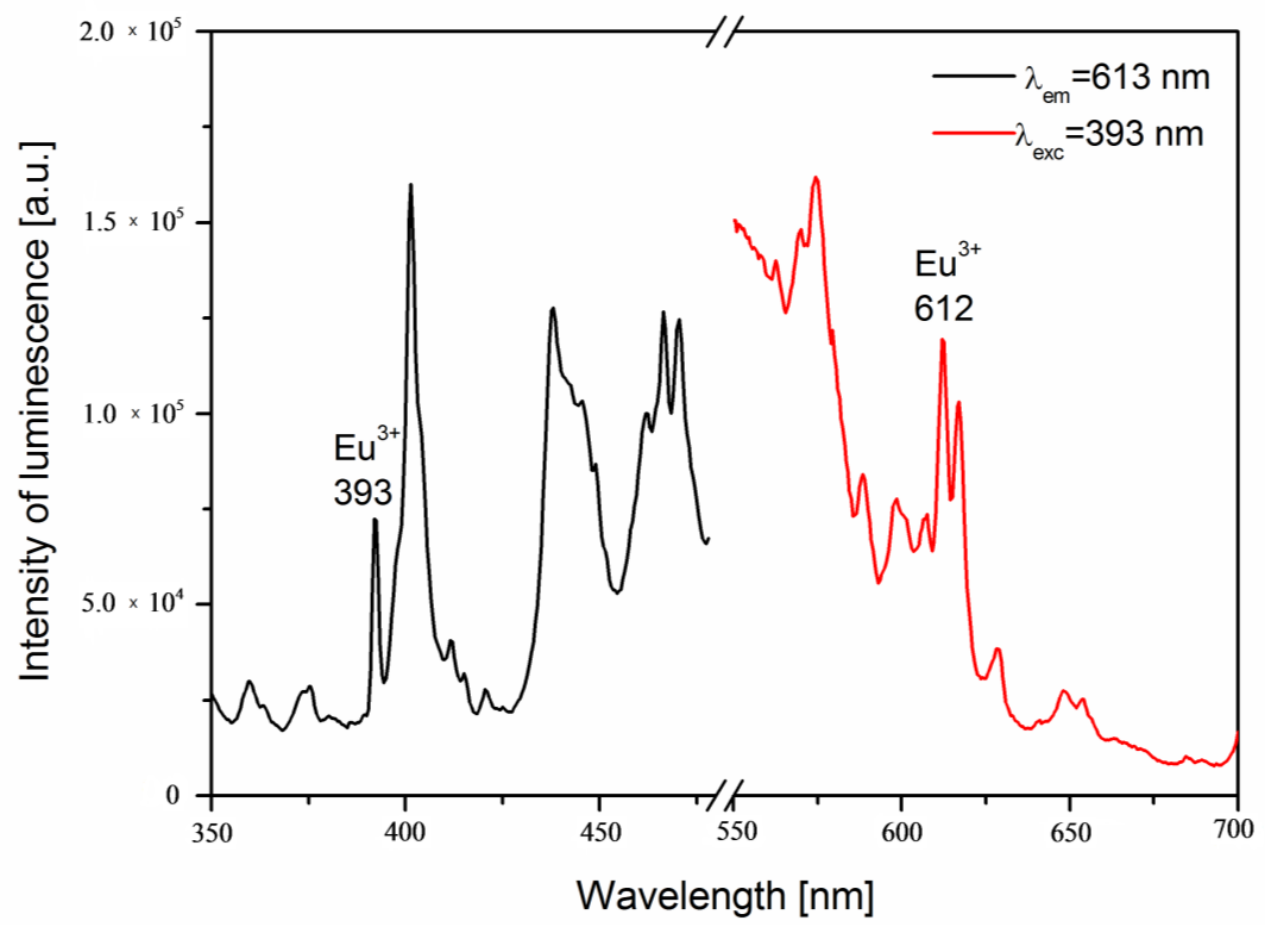

Figure 12. Excitation and emission spectra of $\mathrm{Eu}^{3+}$ in agrellite.

Under excitation $\lambda_{\text {exc }}=321 \mathrm{~nm}$, not only the emission of $\mathrm{Dy}^{3+}(574 \mathrm{~nm})$ but also of $\mathrm{Sm}^{3+}$ and $\mathrm{Pr}^{3+}$ $(562 \mathrm{~nm}, 569 \mathrm{~nm}, 601 \mathrm{~nm}, 607 \mathrm{~nm}$ ), was measured (Figure 9). On the excitation spectra monitored at $562 \mathrm{~nm}$, not only the most convenient bands for $\mathrm{Sm}^{3+}\left(\right.$ and $\left.\mathrm{Pr}^{3+}\right)$ were measured but an intense band of $\mathrm{Ce}^{3+}$ was recorded too. In the excitation spectra of $\mathrm{Sm}^{3+}, \mathrm{Pr}^{3+}$, and $\mathrm{Eu}^{3+}$, the $\mathrm{Ce}^{3+}$ band at 321-323 nm always appeared and it was intense. (Figure 13). This same effect has been measured when luminescence was excited into the $\mathrm{Ce}^{3+}$ emission band, i.e., $388 \mathrm{~nm}$ (Figure 14).

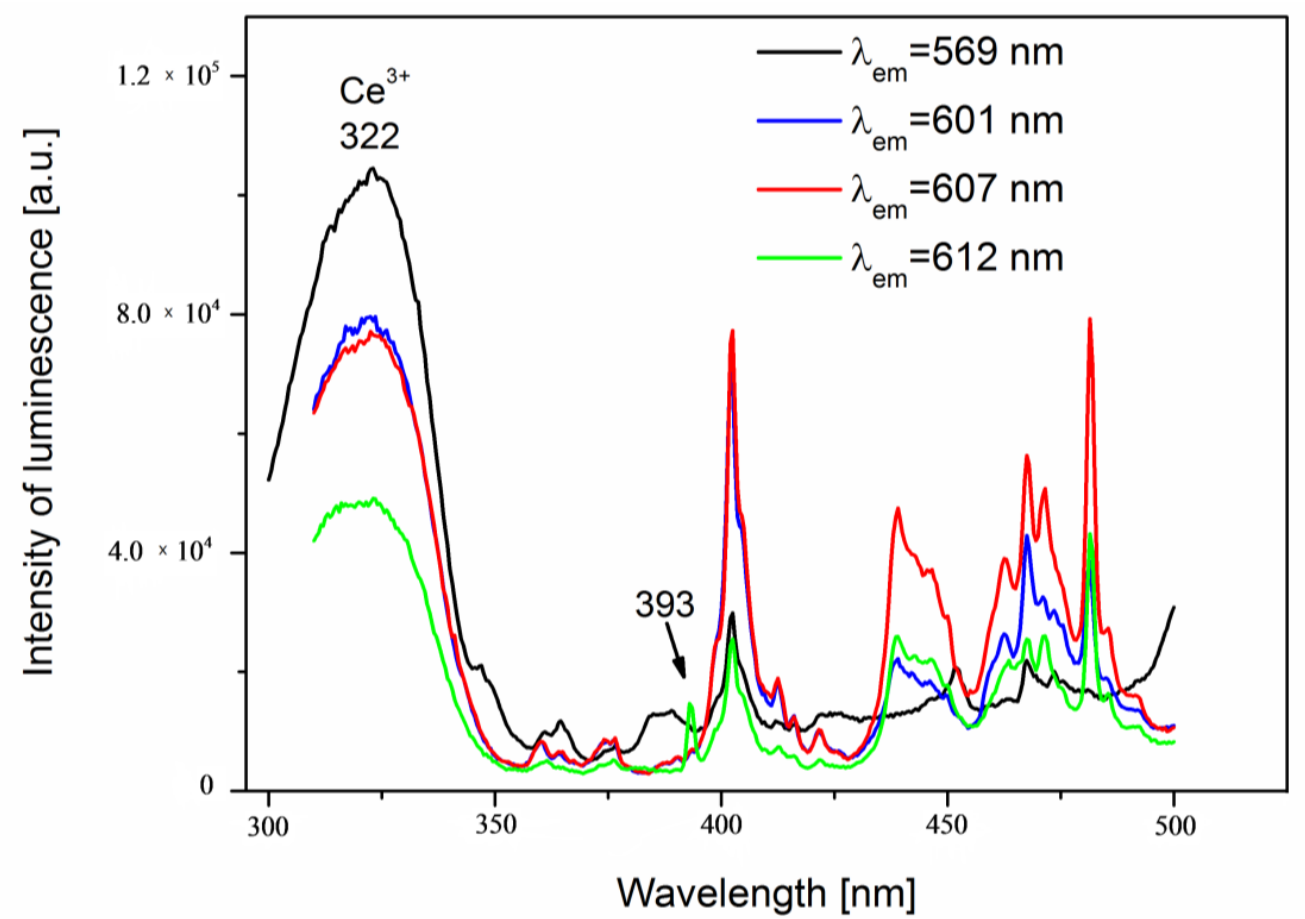

Figure 13. The excitation spectra of $\mathrm{Pr}^{3+}$ and $\mathrm{Sm}^{3+}$ emission in agrellite. 


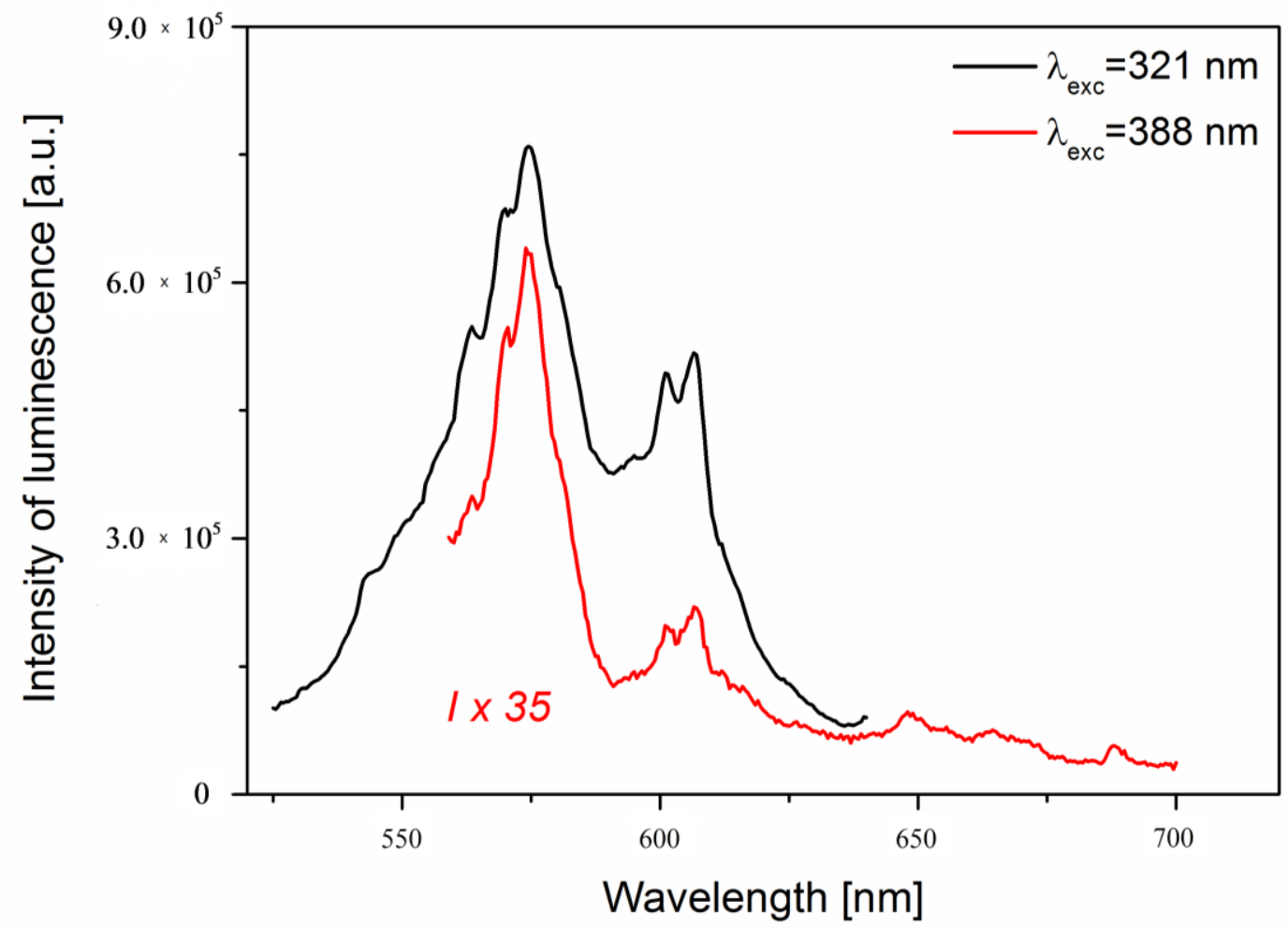

Figure 14. The emission spectra of $\operatorname{Pr}^{3+}$ and $\mathrm{Sm}^{3+}$ under $\mathrm{Ce}^{3+}$ excitations.

The presence of the $\mathrm{Ce}^{3+}$ excitation band in the PLE spectrum of $\mathrm{Dy}^{3+}, \mathrm{Sm}^{3+}, \mathrm{Pr}^{3+}$, and $\mathrm{Eu}^{3+}$ indicated the occurrence of $\mathrm{Ce}^{3+} \rightarrow\left(\mathrm{Dy}^{3+}, \mathrm{Sm}^{3+}, \mathrm{Pr}^{3+}\right.$, and $\left.\mathrm{Eu}^{3+}\right)$ energy transfer process. Upon UV irradiation, electrons from the ${ }^{2} \mathrm{~F}_{5 / 2}$ ground state of $\mathrm{Ce}^{3+}$ are excited into the $5 \mathrm{~d}$ excited state. Some of these electrons return to the ground states $\left({ }^{2} \mathrm{~F}_{7 / 2}\right.$ and $\left.{ }^{2} \mathrm{~F}_{5 / 2}\right)$ of $\mathrm{Ce}^{3+}$ ions, resulting in the violet-blue emissions of $\mathrm{Ce}^{3+}$ due to the $5 \mathrm{~d} \rightarrow 4 \mathrm{f}$ transition. At the same time, owing to the nonradiative resonant energy-transfer, a portion of excited electrons can be transferred into the ${ }^{4} K_{15 / 2,17 / 2}$ excited levels of $\mathrm{Dy}^{3+}$ and then relax, mainly as ${ }^{4} \mathrm{~F}_{9 / 2} \rightarrow{ }^{6} \mathrm{H}_{13 / 2}$ transition. Similarly, another portion of excited electrons can be transferred into excited levels of ${ }^{4} \mathrm{~K}_{11 / 2}$ or ${ }^{3} \mathrm{P}_{2}$ of $\mathrm{Sm}^{3+}$ or $\mathrm{Pr}^{3+}$ and subsequently, the electrons can relax to their ground levels.

\section{Conclusions}

In the studied agrellite crystal, the lanthanide ions form a complex arrangement of luminescence centers. The $\mathrm{f}-\mathrm{f}$ emission of many ions has been distinctly excited by the excitation band of $\mathrm{Ce}^{3+}$. Generally, the mechanism of energy transfer from donor to acceptor ions can be attributed to an exchange interaction or electric multipolar interaction. The average distance $R_{c}$ between the $\mathrm{Ce}^{3+}$ donors and $\mathrm{Sm}^{3+}$ or $\mathrm{Pr}^{3+}$ acceptors was estimated as a value according to the below equation where $C$ is the total concentration of $4 \mathrm{f}^{\mathrm{n}}$ ions in the studied sample, $N$ is the coordination number, and $V$ is the cell volume:

$$
R_{c}=2 \sqrt[3]{\frac{3 \cdot V}{4 \pi \cdot C \cdot N}}
$$

when this value was determined to be $19.38 \AA$ and it is greater than $5 \AA$, the energy transfer process would take place via electric multipolar interaction. The direct confirmation of this conclusion could be obtained by measuring the decay lifetimes of $\mathrm{Ce}^{3+}, \mathrm{Dy}^{3+}, \mathrm{Sm}^{3+}$, and $\mathrm{Pr}^{3+}$ emissions, as well as the changes in luminescence intensities of these ions for samples containing their variable content. It is necessary to carry out measurements for other specimens of agrellite, differing in the content of these ions. 
Contrary to the information on the website [3], the luminescence of $\mathrm{Mn}^{2+}$ has not been observed, although it was stated at $580 \mathrm{~nm}$; similarly, no emission band of $\mathrm{Eu}^{2+}$ which was notified at $410 \mathrm{~nm}$ was observed. Additionally, the emission lines of $\mathrm{Dy}^{3+}$ at $478 \mathrm{~nm}$ or of $\mathrm{Er}^{3+}$ at $522 \mathrm{~nm}$ were not clear. It was observed that the measured emission spectra in the 400-560 nm range show intensive scattering of incident radiation not related to the effect of light reflection from the crystal surface. It can be assumed that it is due to the presence of numerous defects on $\left[\mathrm{Si}_{4} \mathrm{O}_{10}\right]^{4-}$ and will be confirmed after femtosecond excitation measurements.

Some differences have been observed between the emission spectra of agrellite specimens for various localities presented in [4] or [5] and our results. The main reason for these differences is certainly the difference in REE content, although the data contained in [1,2] are incomplete. The agrellite specimen from the Kipawa River studied in the current research contains more Ce and a comparable amount of $\mathrm{Mn}$ and Fe as a sample from Dara-i-Pioz, and it is more than the sample from Yakutia [5]. However, contrary to [1] but similar to [5], we did not measure the emission of $\mathrm{Mn}^{2+}$ as was stated for the specimen from Dara-i-Pioz, and also the emission of $\mathrm{Fe}^{3+}$ tetra and $\mathrm{Eu}^{2+}$ as was shown for the specimen from Yakutia. Compared to previous luminescence results for specimens from the Kipawa River [4], the emissions from $\mathrm{Er}^{3+}, \mathrm{Pr}^{3+}$, and $\mathrm{Eu}^{3+}$ were also measured in the current research.

The most important result of the present research is the demonstration of the phenomenon of effective energy transfer between $\mathrm{Ce}^{3+}$ as a donor and $\mathrm{Pr}^{3+}, \mathrm{Sm}^{3+}$, and $\mathrm{Dy}^{3+}$ as the acceptors. For this reason, a synthetic material based on agrellite, subsidized with the right amount of these ions, can be an efficient white light emitter.

Author Contributions: Conceptualization, M.C.; Investigation/Measurements, M.C. and R.L.; Resources, M.C.; Original Draft Preparation, M.C.; Writing—Review and Editing and Visualization, M.C. and R.L.

Funding: This research project was supported by the Polish National Science Centre (Grant DEC-2011/03/B/ ST10/06320) and by statutory funding from the Faculty of Natural Sciences, Institute of Earth Sciences, University of Silesia.

Conflicts of Interest: The authors declare no conflict of interest.

\section{References}

1. Common Fluorescent Minerals. Available online: https://www.uvminerals.org/minerals/commonfluorescent-minerals (accessed on 25 Octorber 2019).

2. Agrellite. Available online: http://classicgems.net/gem_agrellite.htm (accessed on 25 Octorber 2019).

3. Online Database of Luminescent minerals. Available online: http://www.fluomin.org/uk/accueil.php (accessed on 25 October 2019).

4. Gorobets, B.S.; Rogojine, A.A. Luminescent Spectra of Minerals; RPC VIMS: Moscow, Russia, 2002; 300p.

5. Kaneva, E.; Shendrik, R.; Mesto, E.; Bogdanov, A.; Vladykin, N. Spectroscopy and chemical properties of $\mathrm{NaCa}_{2}\left[\mathrm{Si}_{4} \mathrm{O}_{10}\right] \mathrm{F}$ natural agrellite with tabular structure. Chem. Phys. Lett. 2020, 738, 136868. [CrossRef]

6. Mickens, M.A.; Assefa, Z. Tunable luminescence and white light emission of novel multiphase sodium calcium silicate nanophosphors doped with $\mathrm{Ce}^{3+}, \mathrm{Tb}^{3+}$, and $\mathrm{Mn}^{2+}$ ions. J. Lumin. 2014, 145, 498-506. [CrossRef]

7. Ghose, $\mathrm{S}$.; Wan, C. Agrellite, $\mathrm{Na}(\mathrm{Ca}, \mathrm{RE})_{2} \mathrm{Si}_{4} \mathrm{O}_{10} \mathrm{~F}$ : A layer structure with silicate tubes. Am. Mineral. 1979, 64, 563-572.

8. Gaft, M.; Reisfeld, R.; Panczer, G. Luminescence Spectroscopy of Minerals and Materials; Springer: Berlin/Heidelberg, Germany, 2005; 606p.

9. Czaja, M.B.; Bodył-Gajowska, S.; Mazurak, Z. Steady-state luminescence measurement for qualitative identification of rare earth ions in minerals. J. Miner. Petrol. Sci. 2013, 108, 47-54. [CrossRef]

10. Wang, S.; Song, Z.; Kong, Y.; Liu, Q. Relationship of Stokes shift with composition and structure in $\mathrm{Ce}^{3+} / \mathrm{Eu}^{2+}$-doped inorganic compounds. J. Lumin. 2019, 212, 250-263. [CrossRef]

11. Dorenbos, P.; Andriessen, J.; Marsman, M.; van Eik, C.W.E. On the Stokes shift of the $\mathrm{Ce}^{3+} 5 \mathrm{~d} 4 \mathrm{f}$ luminescence in inorganic crystals. Radiat. Eff. Defects Solids 2001, 154, 237-241. [CrossRef]

12. Zhang, J.; Wang, L.; Jin, Y.; Zhang, X.; Hao, Z.; Wang, X. Energy transfer in $\mathrm{Y}_{3} \mathrm{Al}_{5} \mathrm{O}_{12}: \mathrm{Ce}^{3+}, \mathrm{Pr}^{3+}$ and $\mathrm{CaMoO}_{4}: \mathrm{Sm}^{3+}, \mathrm{Eu}^{3+}$ phosphors. J. Lumin. 2011, 131, 429-432. [CrossRef] 
13. Grzyb, T.; Runowski, M.; Lis, S. Facile synthesis, structural and spectroscopic properties of $\mathrm{GdF}_{3}: \mathrm{Ce}^{3+}$, $\mathrm{Ln}^{3+}\left(\mathrm{Ln}^{3+}=\mathrm{Sm}^{3+}, \mathrm{Eu}^{3+}, \mathrm{Tb}^{3+}, \mathrm{Dy}^{3+}\right)$ nanocrystals with bright multicolor luminescence. J. Lumin. 2014, 154, 479-486. [CrossRef]

14. Caldiño, U.; Lira, A.; Meza-Rocha, A.N.; Pasquini, E.; Pelli, S.; Speghini, H.; Bettinelli, M.; Righini, G.C. White light generation in $\mathrm{Dy}^{3+}$-and $\mathrm{Ce}^{3+} / \mathrm{Dy}^{3+}$-doped zinc-sodium-aluminosilicate glasses. J. Lumin. 2015, 167, 327-332. [CrossRef]

15. Zeng, H.; You, F.; Peng, H.; Huang, S. Energy transfer from $\mathrm{Ce}^{3+}$ to $\mathrm{Tb}^{3+}, \mathrm{Dy}^{3+}$ and $\mathrm{Eu}^{3+}$ in $\mathrm{Na}_{3} \mathrm{Y}\left(\mathrm{BO}_{3}\right)_{2}$. J. Rare Earths 2015, 33, 1051-1055. [CrossRef]

16. Nair, G.B.; Dhoble, S.J. White light emission through efficient energy transfer from $\mathrm{Ce}^{3+}$ to $\mathrm{Dy}^{3+}$ ions in $\mathrm{Ca}_{3} \mathrm{Mg}_{3}\left(\mathrm{PO}_{4}\right)_{4}$ matrix aided by $\mathrm{Li}^{+}$charge compensator. J. Lumin. 2017, 192, 1157-1166. [CrossRef]

17. Li, B.; Huang, X.; Lin, J. Single-phased white-emitting $\mathrm{Ca}_{3} \mathrm{Y}(\mathrm{GaO})_{3}\left(\mathrm{BO}_{3}\right)_{4}: \mathrm{Ce}^{3+}, \mathrm{Tb}^{3+}, \mathrm{Sm}^{3+}$ phosphors with high-efficiency: Photoluminescence, energy transfer and application in near-UV-pumped white LEDs. J. Lumin. 2018, 204, 410-418. [CrossRef]

18. Dev, K.; Selot, A.; Nair, G.B.; Barai, V.L.; Haque, F.Z.; Aynyas, M.; Dhoble, S.J. Energy transfer from Ce $\mathrm{C}^{3+}$ to $\mathrm{Dy}^{3+}$ ions for white light emission in $\mathrm{Sr}_{2} \mathrm{MgAl}_{22} \mathrm{O}_{36}: \mathrm{Ce}^{3+}, \mathrm{Dy}^{3+}$ phosphor. J. Lumin. 2019, 206, 380-385. [CrossRef]

19. Tarashchan, A.N. Luminescence of Minerals; NaukovaDumka: Kiev, Ukraine, 1978.

20. Lisiecki, R.; Głowacki, M.; Berkowski, M.; Ryba-Romanowski, W. Contribution of energy transfer process to excitation and relaxation of $\mathrm{Yb}^{3+}$ ions in $\mathrm{Gd}_{3}(\mathrm{Al}, \mathrm{Ga})_{5} \mathrm{O}_{12}: \mathrm{Re}^{3+}, \mathrm{Yb}^{3+}\left(\mathrm{RE}^{3+}=\mathrm{Tm}^{3+}, \mathrm{Er}^{3+}, \mathrm{Ho}^{3+}, \operatorname{Pr}^{3+}\right) . J$. Lumin. 2019, 211, 54-61. [CrossRef]

21. Kaur, P.; Singh, D.; Sing, T. Sm ${ }^{3+}$ and $\mathrm{Gd}^{3+}$ Co-doped lead phosphate glasses for $\gamma$-rays shielding and sensing. J. Lumin. 2019, 209, 74-88. [CrossRef]

22. Khan, I.; Rooh, G.; Rajaramakrishna, R.; Sirsittipokakun, N.; Kim, H.J.; Wondeeying, C.; Kaewkhao, J. Development of $\mathrm{Eu}^{3+}$ doped $\mathrm{Li}_{2} \mathrm{O}-\mathrm{BaO}-\mathrm{GdF}_{3}-\mathrm{SiO}_{2}$ oxyfluoride glass for efficient energy transfer from $\mathrm{Gd}^{3+}$ to $\mathrm{Eu}^{3+}$ in red emission solid state device application. J. Lumin. 2018, 203, 515-524. [CrossRef]

23. Fan, B.; Qi, S.; Zhao, W.; Li, S.; An, S. Photoluminescence properties and energy transfer of red phosphors $\mathrm{Y}_{2} \mathrm{P}_{4} \mathrm{O}_{13}: \mathrm{Gd}^{3+}, \mathrm{Eu}^{3+}$. J. Lumin. 2018, 196, 520-524. [CrossRef]

24. Gupta, P.; Bedyal, A.K.; Kumar, V.; Khajuria, Y.; Sharma, V.; Ntwaeaborwa, O.M.; Swart, H.C. Energy transfer mechanism from $\mathrm{Gd}^{3+}$ to $\mathrm{Sm}^{3+}$ in $\mathrm{K}_{3} \mathrm{Gd}\left(\mathrm{PO}_{4}\right)_{2}: \mathrm{Sm}^{3+}$ phosphor. Mater. Res. Express 2015, 2, 076202. [CrossRef]

25. Wantana, N.; Kaewjaeng, S.; Kothan, S.; Kim, H.J.; Kaewkhao, J. Energy transfer from Gd ${ }^{3+}$ to $\mathrm{Sm}^{3+}$ and luminescence characteristics of $\mathrm{CaO}-\mathrm{Gd}_{2} \mathrm{O}_{3}-\mathrm{SiO}_{2}-\mathrm{B}_{2} \mathrm{O}_{3}$ scintillating glasses. J. Lumin. 2017, 181, 382-386. [CrossRef]

26. Liu, C.; Liu, J.; Lu, S.; Chen, B.; Zhang, J. Energy migration and transfer of $\mathrm{Tm}^{3+}-\mathrm{Gd}^{3+}-\mathrm{Dy}^{3+}$ system in $\mathrm{NaGdF}_{4}$ under VUV and UV excitations. J. Lumin. 2007, 122, 970-972. [CrossRef]

27. Reisfeld, R.; Greenberg, E.; Biron, E. Energy transfer between $\mathrm{Gd}^{3+}$ and $\mathrm{Sm}^{3+}$. The effect of Gd $\mathrm{C}^{3+}$ on quenching of $\mathrm{Sm}^{3+}$ and intensity parameters of $\mathrm{Sm}^{3+}$ in borate glasses. J. Solid State Chem. 1974, 9, 224-233. [CrossRef]

(C) 2019 by the authors. Licensee MDPI, Basel, Switzerland. This article is an open access article distributed under the terms and conditions of the Creative Commons Attribution (CC BY) license (http://creativecommons.org/licenses/by/4.0/). 